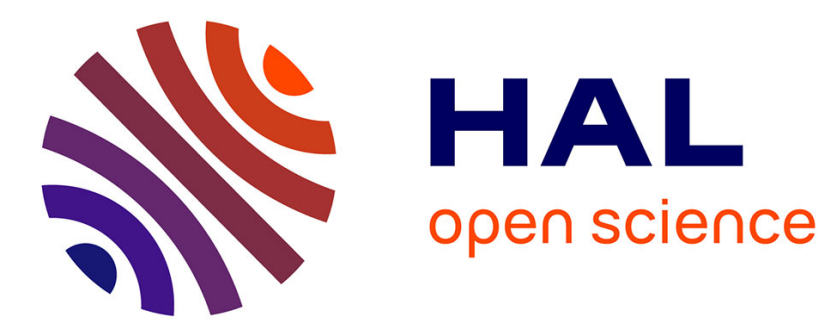

\title{
How To Be a 'Wise' Researcher: Learning from the Aristotelian Approach to Practical Wisdom
}

\author{
Sandrine Frémeaux, Thibaut Bardon, Clara Letierce
}

\section{To cite this version:}

Sandrine Frémeaux, Thibaut Bardon, Clara Letierce. How To Be a 'Wise' Researcher: Learning from the Aristotelian Approach to Practical Wisdom. Journal of Business Ethics, 2020, 171, pp.667-681. 10.1007/s10551-020-04434-3 . hal-03232780

\section{HAL Id: hal-03232780 \\ https://hal.science/hal-03232780}

Submitted on 22 May 2021

HAL is a multi-disciplinary open access archive for the deposit and dissemination of scientific research documents, whether they are published or not. The documents may come from teaching and research institutions in France or abroad, or from public or private research centers.
L'archive ouverte pluridisciplinaire HAL, est destinée au dépôt et à la diffusion de documents scientifiques de niveau recherche, publiés ou non, émanant des établissements d'enseignement et de recherche français ou étrangers, des laboratoires publics ou privés. 
ARTICLE TITLE :

HOW TO BE A 'WISE' RESEARCHER:

LEARNING FROM THE ARISTOTELIAN APPROACH TO PRACTICAL WISDOM

\section{AUTHORS AND AFFILIATIONS :}

Sandrine Frémeaux, Professor, Audencia Business School, France

Department of Management, 8 route de la Jonelière, Nantes, France, 0033272029497

sfremeaux@audencia.com

Thibaut Bardon, Professor, Audencia Business School, France

Clara Letierce, Doctoral Student, Audencia Business School, France

\section{CORRESPONDING AUTHOR :}

Sandrine Frémeaux, Professor, Audencia Business School, France

Department of Management, 8 route de la Jonelière, Nantes, France, 0033272029497

sfremeaux@audencia.com 
HOW TO BE A 'WISE' RESEARCHER:

\title{
LEARNING FROM THE ARISTOTELIAN APPROACH TO PRACTICAL WISDOM
}

\begin{abstract}
How can you act ethically in a publication system that attempts to regulate research activity in a way that you might find, in many respects, to be unethical? In this article, we address this question by drawing on the Aristotelian perspective of practical wisdom. Drawing on thirty semi-structured interviews with academics working in French business schools, we outline different means through which they act 'wisely' by deliberating and focusing on what is within their power and in line with their best judgment. In particular, we show how some of them succeed in performing virtuous actions both within the publication system and beyond.
\end{abstract}

\section{Keywords}

Aristotle, Business School, Managerialism, Practical wisdom, Publish or perish. 


\section{How to be a 'wise' researcher:}

\section{Learning from the Aristotelian approach to practical wisdom}

Academic research in business schools is an intellectual activity that is particularly affected by managerialism, which "invite[s] and reward[s] academics who willingly restrict their work to duties and activities that provide the greatest measurable, visible output for the lowest risk and least effort" (Willmott, 1995, p. 1024). This technicist vision of research activity risks leading to a situation where the number of published articles in high-ranking publications is favored over the quality of the scientific approach, luring academics away from learning, reflecting, and developing their creative thinking (Butler and Spoelstra, 2012; Clarke and Knights, 2015; Edwards and Roy, 2017).

Many scholars have denounced this trend by adopting a critical approach that they consider to be somewhat paradoxical (Butler and Spoelstra, 2012; Dunne et al., 2008; Wilmott, 2011) because it involves criticizing the logic of excellence in articles published in 'excellent' journals. This form of resistance, which critical academics have frequently used in scholarly journals (Butler and Spoelstra, 2012; Butler et al., 2018), is not the only alternative when faced with academic managerialism (Anderson, 2008; Jeanes, 2017). Another possibility is to attempt to take virtuous action, considering the constraints imposed by this environment. Such an ethical stance, however, has not previously received much academic attention. As notable exceptions, Archer (2008) and Robinson et al. (2017) have discussed early career academics' abilities to act according to their own values. Alvesson, Gabriel, and Paulsen (2017) formulate 
programmatic propositions at individual, organizational, and governmental levels, which would promote 'meaningful' research that is relevant on both social and personal levels.

In this paper, our aim is to add to this discussion by documenting how academics can take virtuous actions in the 'publish or perish' system. To do so, we build on the Aristotelian perspective of practical wisdom, which we understand as carrying out phronetic actions-in other words, thoughtful actions that are within our power and in line with our best judgment (Aristotle, Nicomachean Ethics, trans. 2002; hereafter referred to as NE). Practical wisdom thus derives from the ethical choice of developing a virtuous ethos (habit) of deliberation, judgment, and execution (Beabout, 2012; Sison et al., 2012) and involves performing deliberate actions in accordance with our power and best judgment (Bachmann et al., 2018).

In line with this perspective, we analyze how thirty academics working in three French business schools attempt to act 'wisely' within the managerialist system in which they are embedded. We show how researchers confronted with a managerialist research system focus on what they believe to be within their power and in line with their best judgment. To do this, they adopt different means of acting virtuously that enable them (or not) to meet the system's expectations.

The article is organized as follows. In the first section, we review existing studies that discuss how the publish or perish system attempts to regulate research activity in a way that raises many ethical concerns. The second section focuses on the Aristotelian approach to practical wisdom (phronesis) and highlights what constitutes a virtuous action from this perspective. The third section describes the methodology of our empirical study, which consists of thirty semi-structured interviews with academics from three different business schools, and explains how we carried out data collection and analysis. Findings are presented in the fourth section, where we present different attempts by researchers to perform virtuous actions in accordance 
with their power and their best judgment. The final section focuses on our theoretical contribution to the literature on managerialism in academic research.

\section{Literature review}

\section{Restrictions on freedom in academia}

Academic managerialism has been criticized for pushing researchers to conform with the requirements of high-ranking journals in order to maximize their research productivity (Butler and Spoelstra, 2014; Locke and Spender, 2011; Murillo and Vallentin, 2016). Alvesson et al. (2017) emphasize that academics are not only victims of this publish or perish system but are also accomplices who reproduce it by proactively engaging in this publication race. This results in a publication game that exerts strong pressure on academics for choosing the research questions, theoretical perspectives, and methods that will permit them to publish as fast as possible in the best-ranked outlets (Willmott, 1995). Academic managerialism has also been criticized for not allowing researchers sufficient time to reflect deeply on their topic and to explore unconventional theoretical and empirical territories (Clarke and Knights, 2015; Clarke et al., 2012; Edwards and Roy, 2017).

Existing studies demonstrate that academics may adopt several (un)ethical positions within such a publish or perish environment, which attempts to impose how research activity is conceived and realized. First, academics may accept the publication game and 'play along' because it makes them feel recognized as successful researchers (Clarke and Knights, 2015; Roberts, 2005). This leads them "to comply with or conform to the demands of the performance culture, enticed, seduced and compensated by its potential rewards" (Clarke and Knights, 2015, p. 1879). In line with this, Gadamer (2004) and Butler and Spoelstra (2012) have noted that the publication game exerts a profound influence on the subjectivity of researchers who become more focused on material and social recognition than on conducting 
relevant research. Davies and Peterson (2005) argue that it is not possible to play the publication game without a neo-liberal mindset because, over time, it necessarily transforms academics into individualists who focus on publication opportunities as well as elegant publishable models. In all cases, critical studies state that complying with the publish or perish system leads academics to adopt many unethical behaviors such as being more interested in "how can I get published" rather than "how can I do good research" (Alvesson et al., 2017, p. 28), neglecting other academic activities such as teaching (Clarke and Knights, 2015), distorting the complex reality of the business world in order to produce "good stories" (Butler and Spoelstra, 2012; Pearce and Huang, 2012; Willmott, 2011) or attaching their names to papers to which they have not actually, or only barely, contributed in exchange for providing their colleagues with the opportunity to do the same (Edwards and Roy, 2017). By encouraging such unethical behaviors, the publication system not only reduces scientific progress and the quality of research but also risks reproducing the "perversion of natural selection" (Edwards and Roy, 2017, p. 53). Indeed, those who are comfortable with such an individualistic, performance-driven, and opportunistic system are promoted while others are excluded, creating, among the latter, a feeling of failure and a sense of shame that may even prevent them from expressing a critical analysis of the system (Clarke and Knights, 2015). The result is a widespread cynicism among academics on the value of academic research (Alvesson et al., 2017; Alvesson and Spicer, 2016; 2018), leading them to treat their work as a game in which they see themselves as players.

The second position adopted by academics corresponds to that taken by the critical scholars who authored the studies discussed in the previous paragraph (e.g. Clarke and Knights, 2015; Edwards and Roy, 2017). By demonstrating how academic managerialism pressurizes researchers and can lead them to adopt unethical behaviors, these studies represent instances of (discursive) resistance to the publish or perish regime. This position, however, raises 
several ethical concerns. Indeed, criticism of the publish or perish regime may seem contradictory to the practice of publishing in the best-ranked journals that epitomize such a system (Butler and Spoelstra, 2012; Wilmott, 2011). The proliferation of articles criticizing the publication game may, paradoxically, be a sign of a strengthening within the system. Moreover, this approach is limited to deconstructing the system and does not propose a realistic and pragmatic alternative that could easily be implemented on a daily basis. In addition, the critical approach is based on the adoption of a distant position that suggests that researchers would be able to extricate themselves from the constraints they denounce, simply by engaging in this approach.

It is possible that a third position exists, one that consists in attempting to act ethically in the publish or perish system. Archer (2008) shows how some early career academics resist or protect themselves from academic managerialism, while Robinson et al. (2017) argue that early career academics can bend the rules according to their own values. After analyzing what leads to the proliferation of meaningless research, Alvesson et al. (2017) formulate recommendations about what individual researchers, research institutions (including universities and academic journals), and even governments can do to promote meaningful research that contributes to the "common good" (ibid, p. 20). At an individual level, they argue particularly that researchers can adopt a "nomadic" rather than "formulaic" approach, which produces "polymorphic researches" (ibid, p. 90) by moving across areas, methods, writing styles, and target audiences. By doing this, they say, researchers may have a chance to say something new and socially relevant.

Thus, the possibility for researchers to act ethically in the publish or perish system has already been identified; however, this idea is still in its infancy. In this study, we add to this discussion by relying on an Aristotelian perspective of practical wisdom in order to document how researchers attempt to act 'virtuously' in the publish or perish system. 


\section{Aristotelian practical wisdom: an ethical reflection on virtuous actions}

The notion of practical wisdom has been the subject of a number of recent studies in business ethics literature. In this respect, Bachmann et al. (2018) have carried out a comprehensive review in order to show how the different traditions of research on practical wisdom complement one another. Likewise, Bardon et al. (2017) have highlighted the use of the concept of phronesis in recent studies and the close relationship between this concept and sagacity (Holt, 2006), prudential judgment (Nonaka et al., 2014), and capacities (Shotter and Tsoukas, 2014).

For Aristotle, practical wisdom is associated with making ethical choices involving the performance of virtuous habits, which, in turn, allow for the development of a stable virtuous character over time. Thus, ethics are not conceptual contents that can be learnt but are in fact derived from practical experience. We are therefore invited to think about our ethical stance by working on ourselves on a day-to-day basis through intellectual and spiritual exercises in order to take virtuous action (NE, Book I, 6).

Since practical wisdom consists in attempting to deal in the most virtuous way with the constraints of the environment in which we are embedded, it differs from the more trivial notions of acting 'freely' without constraint or acting 'independently' of constraints. Practical wisdom consists in performing thoughtful actions in accordance with our sense of virtue given constraints - in other words, by taking into account the particular circumstances with which we are confronted. This understanding of what it means to act virtuously, based on Aristotle's approach to phronesis, has already been discussed in management literature, but not in an academic context. Indeed, existing studies have mainly focused on the concept of virtuous leadership (Küpers and Pauleen, 2013; Shotter and Tsoukas, 2014) and virtuous management (Bardon et al., 2017), and, notably, have reflected on how virtuous practitioners produce alignment between right thinking, right desire, and right action by creating harmony among 
reason, emotions, and behaviors (Hartmann, 2013; Sison and Ferrero, 2015). In particular, a virtuous leader or manager considers which goals and means are worth pursuing rather than just simply maximizing target quantities (Bardon et al., 2017; Sison et al., 2012). Without deliberation, one would be condemned to act blindly or to undergo passively the situation in which one is embedded. Deliberating allows us to think about the different options that are offered to us and to voluntarily choose the best course of action according to our judgment. Aristotle refers to both individual and collective deliberation using the same term: "bouleusis" (NE, Book III, 1). Individual deliberation can thus be a first step towards collective deliberation and refers, as Archer (2003) suggests, to the idea of internal conversationunderstood as a practical reflection conducted at the individual level, which involves thinking both intellectually and based on one's own personal experience. Specifically, Aristotle invites us to engage in this process of deliberating on what is within our power and in line with our best judgment.

Firstly, Aristotle clearly states: "we deliberate about things that are in our power and can be done" (NE, Book III, 3). Indeed, he suggests a distinction between what is operable—what we can act on - and what is non-operable - what we cannot act on. More specifically, the philosopher opposes what is absolutely non-operable, that is what cannot be changed by anyone (such as the course of the stars) and what is relatively non-operable, that is what only certain people can change. Of course, deliberation should not concern things that are absolutely non-operable. Aristotle specifies that the power that we have over relatively nonoperable issues depends on each of us. He notes that "we do not deliberate even about all human affairs; for instance, no Spartan deliberates about the best constitution for the Scythians" (NE, Book III, 3). This means that we should focus on actions that depend upon us and abandon those that are not within our power, either because they are impossible to act 
upon per se, or because they can only be acted upon by other people. From this perspective, showing practical wisdom involves focusing on what is within our power.

Secondly, Aristotle argues that acting virtuously implies deliberating about how we can perform actions according with our best judgment. Aristotle emphasizes that: "we deliberate not about ends, but about means" (NE, III, 5). Commentators widely recognize that this does not exclude a reflection on moral purpose (Cammack, 2013), as Aristotle assumes that this deliberation necessarily involves the pursuit of a moral purpose (NE, Book VI, 5 and 10), one that is guided by the willingness to seek a virtuous life and happiness or eudaimonia (Kolnai, 2001, Cammack, 2013): “every skill and every inquiry, and similarly every action and rational choice is thought to aim at some good; and so the good has been aptly described as that at which everything aims" (NE, Book I, 1). In order to make a deliberate choice, Aristotle invites virtuous people to know the causes of their actions and to strive to determine whether what seems desirable conforms with virtue (NE, Book II, 5 and 6). Virtuous people seek not only to resist unwise pleasures that flatter pride and lead to losing sight of noble causes, but also to avoid acrasy, which is defined as an individual acting against his/her best judgment because of a "weakness of will". Aristotle notes that acrasy is distinct from bad deeds (NE, Book III). Whereas bad deeds are voluntary and evil in purpose, acratic people are merely ignorant: certainly, they are aware of acting contrary to their best judgment, but they believe that knowledge of virtues is sufficient, without needing to become virtuous through good habits. In other words, acratic people know that they are moving away from virtue, but they do not know how to attain it because they lack good habits. Acting according with our best judgment attests to our strength of will and our ability to adopt the right habits.

Therefore, for Aristotle, acting virtuously involves asking ourselves which actions are within our power and in line with our best judgment given the specific context in which we are embedded. This deliberation nurtures virtue, or more specifically, "virtue, then, is a state of 
character concerned with choice, lying in a mean, i.e. the mean relative to us, this being determined by a rational principle, and by that principle by which the man of practical wisdom would determine it" (NE, Book II, 6).

In line with this interpretation, the objective of this study is to examine how researchers act virtuously given the constraints of the publication system.

\section{Methods}

The development of academic managerialism within business schools is acknowledged as an issue in Anglo-Saxon contexts (Mitroff, 2004; Murillo and Vallentin, 2016; Sigurjonsson et al., 2014, 2015; Tourish and Willmott, 2015) but also in France (Dubois and Walsh, 2017) where our empirical field is situated.

Historically, French business schools were 'semi-public' entities that pursued 'public interests' and were largely subsidized by public funds (mainly through Chambers of Commerce), but they were governed by private laws, unlike fully public entities such as universities and most engineering schools (Callet, Gattet and Dessimond, 2018).

For the last 15 years, most business schools have been undergoing rapid privatization due to a state-level decision to drastically reduce (if not suppress) public funding (ibid, 2018). Today, almost all of the business schools have achieved self-financing through the introduction of cost-optimization policies, a significant increase in students' fees, the creation of many 'cashgenerating' programs, and the launching of fundraising campaigns targeting private companies and alumni. Recently, several of them have even changed their historical nonprofit status for a 'for profit' one in order to allow private funds to enter their capital (ibid, 2018). At faculty level, this new financing model has manifested itself in a proliferation of auditing, monitoring, and other management practices that are typical of the private sector and 
the promotion of a strong publish or perish culture exhorting academics to publish in topranked journals.

In France, business schools have been much more affected by academic managerialism than public universities, including the Institut d'Administration des Entreprises (IAE) that are the management schools of public universities (Callet et al., 2018). Business schools thus constitute an ideal setting for our research, as their academics have been brutally exposed to new managerialist systems and, as a consequence, to the ethical issues associated with them. In this context, we could reasonably expect to get access to compelling accounts of how interviewees deliberate about their conduct in this new regime.

Between January and July 2018, we conducted thirty semi-structured interviews with academics working in three French business schools, the first in the top five (BS1), the second in the top ten (BS2), and the third in the top twenty (BS3) of Le Monde's 2018 ranking based on the average of the five French rankings (L'Étudiant, Le Figaro, Challenges, Le Point, and Le Parisien). These French business schools adopt slightly different publication systems. BS1 and BS2 determine the achievement of objectives and bonus payments based on publication in high-ranking publications, using the French CNRS (Centre National de la Recherche Scientifique) ranking and international rankings such as the Association of Business Schools' Academic Journal Guide (ABS List) and the Financial Times 45 (FT45). BS3 only considers publication in the best journals when awarding bonus payments; however, when considering whether targets have been reached, it not only focuses on high-ranking academic publications but also strives to recognize different activities within research. We thus examine how academics deliberate about their conduct in contexts that are characterized by various degrees of pressure to publish, with the aim of documenting the greatest range of ways of acting wisely. 
This led us to use a heterogeneous sampling approach in terms of gender, age, employment tenure, status, and discipline: 13 of the respondents were women; 19 interviewees were under forty-five years old; 16 interviewees defended their $\mathrm{PhD}$ more than ten years ago; 14 of the respondents had full professor status; and the respondents worked in different scientific disciplines (economics, human resources management, strategy, finance, marketing, and ethics). Scientific achievements were also heterogeneous: according to the criteria outlined by Butler and Spoelstra (2012), 14 of our respondents had an excellent publication record because they had published a minimum of four papers in three- or four-star journals over the previous six years; the remaining interviewees had published in at least one- or two-star journals during the same period. Table 1 below presents the main characteristics of our sample:

INSERT TABLE 1 ABOUT HERE

All the interviews were recorded and transcribed; this allowed us to focus on the researchers' answers as the interview continued. The interviews were conducted with a set of predetermined questions using a semi-structured interview guide. Initially, we provided a brief description of the study and assured respondents that all information would be kept confidential. Having confirmed the sociodemographic characteristics of the interviewees, we began the interview with two open-ended questions: "What are the different stages of your career that led you to do research?" and "Can you describe your research activity?" Follow-up questions were prepared in order to obtain clarification or to cover all aspects of the interviewees' experience as researchers (e.g. "What is the research evaluation system in your school?"; "What were your initial ideals regarding research?"; "How do you choose your 
scientific themes?"; "What are your primary motivations for carrying out your current research?"; "What research ideas have you rejected?"; "What image do you have of yourself as a researcher?").

While asking interviewees to tell us their own story as researchers, our objective was to encourage them to speak of their experience, thereby gaining access to how they enact their world as well as themselves (Weick, 1995; Boyce, 1995). During the interviews, they produced fragmented, polyphonic, and occasionally contradictory accounts that we decided to make available to readers by conducting a narrative thematic analysis (Boje, 2001).

The first two authors thus reviewed the transcripts independently and generated a list of conceptual categories by identifying thematic accounts in relation to our topic. To do so, we first approached the dataset with two broad questions in mind: "According to the respondents, how does the publish or perish regime attempt to regulate research activities?" and "How do respondents reflect on their own conduct in such a context?" To address the first question, we generated separate thematic categories based on respondents' comments and then discussed these together until a consensus was reached about the different ways through which the publish or perish regime attempts to regulate research activities according to the respondents. To address the second question, we identified and sorted thematically all quotations in which respondents consider their own actions. This coding was influenced by our reading of Aristotle since we focused particularly on quotations in which respondents evoke how they act in accordance with their own power and in line with their best judgment. This process included many iterations and discussions between the authors of this article and permitted the emergence of six distinct ways through which respondents act as wise researchers - that is, in ways that they consider as 'virtuous' given the constraints with which they are confronted. We ultimately decided to have two broader categories, namely 'acting virtuously within the publication system' and 'acting virtuously beyond the publication system'. The result of this 
coding process is presented in the next section. Accordingly, we adopted a narrative thematic approach as a representational strategy in order to capture the diversity of meanings that respondents give to their own experience (Weick, 1995). The goal, therefore, is also to produce a story that readers can compare with their own experience as researchers (Rhodes and Brown, 2005).

\section{Results}

I would like to keep this thirst for research, this intellectual interest pure, free, devoid of any personal interest ... I believe that this is what research is for, to move away from a dogmatic vision. (\#19)

All respondents formulate criticisms against the publish or perish system, observing that it attempts to regulate research activity in a way that is limiting and that raises ethical concerns.

In particular, almost all respondents feel constrained by editorial requirements that limit their ability to choose certain topics that they consider as relevant and worthwhile, to use what they believe is the most appropriate method, to develop certain ideas, or to present their thinking in certain ways. Many respondents highlight the risk of delivering simplified and distorted analysis that does not reflect the complexity of reality and of their intellectual activity. This situation can generate important frustrations among respondents:

What frustrates me is that we lie a lot. Of course, we have the brilliant idea right from the start, we stumble upon the right literature, everything is planned and we remove everything that would not fit with the results, it bothers me enormously ... This work of reconstruction to have something very smooth that seems a beautiful story with no rough edges, it bothers me a lot. (\#15)

A significant number of respondents also criticize the increasing pressure on publication objectives, which pushes them to adopt instrumental, opportunistic, and short-term logics in 
order to "spew out top-ranking articles" (\#26). Many complain about having less time for empirical observation, reading, and comprehension. One interviewee even states that it is “embarrassing to say I'm going to read" (\#28). Likewise, some respondents note that the publish or perish system pushes them to tactically choose who they collaborate with on research projects:

We work with people who are recognized in the field, who are used to publishing. We do not choose these collaborations on the basis of friendship, but we look for people who are real research professionals. (\#21)

Many respondents also highlight the fact that the current system attempts to dictate the format of their research outputs and their target audience since research articles in top-ranked journals are much more valued than other research outputs:

I remember in the evaluation interview that I was told: But why do you publish so many books? ... You have to publish articles, books do not count, so do not write books. (\#11) Some are worried that the publish or perish system is causing researchers to lose sight of the raison d'être of research activity, which for them is to participate in a scientific reflection in order to respond to societal issues:

Most papers, even if they end up in very good journals, are papers that are very little read or are quoted only by our peers; they are very little read by companies, by professionals, or by students. (\#27)

One even states that academic pressure could make researchers act "in a very Molière-like way", "in a very petty superior way", "by self-congratulation or self-abhorring", "but apart from that, they are totally unknown" (\#4). Others speak about their perceived lack of social utility as "something that is very painful ... it's a resentment that's pretty general" (\#27). 
All respondents describe at length the pressure resulting from managerialism, arguing that it is “quite stressful” (\#13) and generates "a lot of insecurity” (\#22).

\section{Focusing on what, they believe, is within their power and in line with their best judgment}

Focusing on what is within their power

Despite these criticisms, all respondents assert that it is beyond their power to fight against the publish or perish regime, which, they say, "is a more global, broader problem that goes beyond school governance, which is found in all schools" (\#28):

It is the world of business schools in France and throughout the world that is turning towards a more quantitative than qualitative logic. (\#27)

The problem is not the school, it's the system... The accreditations all work with the same rankings. (\#11)

A couple of respondents even use this line of reasoning to justify why they have accepted, often with regret, to play the publication game despite their ethical reservations regarding this new regime:

We are evaluated based on the number of stars that we bring back, so I concentrated on the production of starred publications (...) I regret it, of course, I came into this business because I wanted to do things that I like but here the job is to publish. (\#27)

This freedom should be sacrificed to publish because we have the freedom to participate but we don't have the freedom to be (...) So, I don't have this freedom. (\#22)

Although highly critical of the publication game, some respondents attempt to further justify why they continue to participate by emphasizing that it provides them a "feeling of selfefficacy" (\#5). One of the respondents observes that "you take the drug because you need it just to feel normal. If I publish less, I'm going to feel like I'm a failure; that's my problem" 
(\#12). Others explain their behavior by stating that it would be personally too costly not to participate in the publication game and even more risky to fight aggressively against it:

I confess, I don't try to fight against the system, against the whole system, because I don't have the energy, it's a little bit too much. (\#11)

It's hard to get out of this system (...) We want to keep our jobs and we have children to raise. (\#8)

Most respondents do not see themselves as adopting an acratic behavior (or at least are not very talkative about it) because they claim that they focus on their power to act, which they occasionally verbalize in terms of freedom: "we always have a little space of freedom" (\#15). Specifically, they say that they concentrate on what is within one's power by "granting oneself the freedom to really do research" (\#28) and "creating for oneself space and time to do it" (\#11). One respondent even argues that, by constraining oneself to reach institution publication objectives, "you earn your freedom so to speak" (\#18) and can therefore carry out other activities not required by the system.

Nevertheless, several respondents feel that their power to act is shrinking over time due to the constant increase of institutional pressures: "I would like to go back thirty years sometimes, where I think the margins of freedom were greater" (\#19). The majority of senior respondents believe that they have more room for maneuver than younger researchers, and thus potentially more options within their power:

At that time, there was not the crazy pressure that there is now ... now it's incredibly competitive, it's where it's crazy (...) but for me, nothing bad can happen, I cannot go any further in my career. (\#2) 
In contrast, young and middle-aged respondents are particularly worried about the longevity of their power to act within the interstices of the system due to the increasing publish or perish pressure:

I still have the chance to work in an institution that tolerates the ugly duckling that I can be, but maybe tomorrow they will tighten up even more. (\#20)

I want to keep doing research because I like it, but it is evident that I will never be able to keep up the pace because research objectives keep increasing. (\#15)

Some young respondents observe that "they are somewhat locked into the spiral of academic publication ... we have more pressure" (\#8). One respondent even describes himself as "a young professor in his thirties who is a little bit disillusioned by the research system" (\#23). Another respondent goes as far as to evoke the risk of burning out in the long term: "I am still young, I have resources, but maybe if I intend to do it for ten years, I may well be burnt out" (\#7).

Focusing on what is in line with their best judgment

While concentrating on what, they believe, is within their power, most of the respondents state that they attempt to choose their research activities according to their best judgment. Some respondents say that they have become particularly vigilant when they feel the desire to work on a research theme or when they are approached by other researchers for a joint project; they strive to check whether this new research project is worthwhile, relevant, or useful.

A few respondents adopt an intellectual approach when deliberating about whether a project is an appropriate one:

I choose my subject according to my personal, especially intellectual, appetite. That is, a subject that makes me want to think. There are subjects in which I would have no 
interest, and which are useful, interesting for other researchers and for society. But for all that, I wouldn't have any appetite for it. So, first of all, it's going to be an intellectual appetite in relation to a subject. (\#20)

The question of social utility is essential to me. I never thought about doing research to please myself. (...) Research has always had, for me, a purpose, which is its social utility. (\#10)

Others also rely on their personal experience and intuition when deliberating about whether a project is worthwhile: "I try to understand, to pay attention to my emotions, my feelings, to know if this project really suits me" (\#17).

Several senior respondents emphasize that experience plays a central role in this effort of introspection, because it helps them to determine what valuable research projects are and to strengthen their willingness to dedicate themselves to particular issues or activities:

I think that there is also a certain age, a maturity in life, when you start to say to yourself: 'Well, what makes me happy too?' ... You have to acquire a certain maturity.

Do things without much cost, without spending too much time, focusing on what is really good for you, on what is strategic for you. (\#17)

One of the respondents even specifies that research is "an art of living and not a profession", and spontaneously indicates that he would continue this activity, even if he were no longer paid for it: "Even if I were to stop working professionally, I would still do the same thing" (\#4).

Therefore, most respondents insist that focusing on what is within their power and in line with their best judgment is essential, as it enables them to "keep passion and motivation" (\#25) and to "survive in the academic world" (\#7): 
If someone told me: 'You should work on this topic, it's fashionable', that would be the end for me. I think that I would quit, that would be the end. (\#19)

In summary, these respondents mention six ways of acting virtuously within the publication system or beyond, which are presented in more detail below.

\section{Acting virtuously within the publication system}

Taking the time to do quality work

Despite the race for productivity that exists in the publish or perish regime, several respondents, senior and younger ones alike, say that they succeed in doing quality work by allowing themselves to spend long periods of time in the field collecting data: "I need concrete things; what nourishes me is the field" (\#15).

These respondents state that they strive to avoid the compartmentalization of research activities and do not hesitate to denounce it:

On the one hand, we're going to have researchers locked up in offices, we're going to tell them: 'you publish, we don't want to see you in companies because you don't have the time' (...) And then we're going to have other people who are not so gifted ... who are going to go into companies. (\#21)

Other respondents say that they take the time to go back to the classics by reading seminal philosophical, sociological, or economic writings in order to accomplish "good research [which] is, perhaps, research that makes it possible to open minds, to nourish intelligence, to make people want to learn, to question themselves" (\#19).

Almost all the respondents agree that they are having more and more difficulty finding the time necessary to understand a subject: "I have the feeling I'm flitting from one thing to another" (\#11). 
Taking the time to do what they consider high-quality research work enables them to regard themselves as good researchers, however:

The good researcher is one who is interested in and who engages, let's say as a citizen, as a public intellectual, with ... pressing issues of the time. (\#18)

Researchers who think that research is about asking questions, taking the time-five, six, seven years-to publish something that is an article-whatever the journal-or a book, and who take the time to do so, these are the successful researchers. They act in accordance with their values and their visions of research. (\#7)

In line with this, numerous respondents say that they do not only perform research in order to be published in top-ranked journals: "I am not interested in publishing for publishing's sake. So, if the objective is to produce papers, just to produce papers, I have no interest in that. I slow down the pace" (\#20).

\section{Developing a personal vision}

Although the majority of respondents complain that research activity is a "normative" profession (\#16), in which researchers are expected to perform a succession of uncreative tasks in order to achieve a result that meets standards, a few of them consider that it is still possible to develop fulfilling and personal research projects while meeting the standards of top-ranked journals. According to them, standards imposed by top-tier journals do not annihilate the possibility of developing a personal vision, on the condition that one is able "to become aware of their existence, not to let [your]self be absorbed by them", and "to discard those which are deadly" (\#4). Some of them even consider that publication standards help them to elaborate complex and original ideas while using clear and rigorous language. For instance, one respondent identifies why, for him, standards may support both intellectual and scientific reflection: 
I think doing research within a school, within a system, guides me ... It limited me to one area... What the big journals are looking for are ideas that are not conformist but are presented in a conformist way ... I think you have to have disruptive ideas, what we call 'think outside the box', but, in the end, you need to present them in the box. (\#22)

This respondent adds that without this framework, he would tend to "write anything about anything and go anywhere without any direction" (\#22). Likewise, another respondent criticizes "the mediocrity or ease of publishing in journals that do not necessarily have a good reputation", explaining that it is easier to publish "original, clean, and impactful things" (\#26) in better journals: "If you are rigorous, you will produce rigor and leave aside things you are not sure about. You will take the time to be even more rigorous" (\#26).

Becoming an expert on a specific issue

A few respondents state that it is possible to develop a unique expertise while publishing in top-tier journals. For instance, one respondent considers research to be "a discovery-based learning activity" (\#15) while recognizing the need to meet publication objectives: "If we do research, it is not only to publish. It's also because we want to discover, to learn" (\#15).

Certain respondents consider that the requirements imposed by high-ranking journals encourage them to always go further in a certain area and to develop a unique expertise: "A good researcher is not an individual who forages everywhere; a good researcher is someone who specializes" (\#10).

Another respondent notes that the approach of specializing in one research theme is not necessarily easy:

Through this race to publish, we tend to become scattered. I realized that this was not what suited me; it is essential for me to do quality research, to be an expert in my field, and to be able to bring this work together around the same theme. (\#24) 
Some respondents explicitly state that a long period of reflection leads them to refuse some opportunities and to specialize in one research area:

Care must be taken not to lose sight of important fundamental issues that tend to be put on hold when opportunities related to meeting people arise. (\#10)

\section{Acting virtuously beyond the publication system}

Developing a parallel scientific activity

Many respondents, mostly middle-aged and senior ones, state that they grant themselves the right to produce research outputs other than journal articles-including book chapters, working papers or less demanding journals—-because, they say, it offers them the possibility to produce research differently and to target other audiences. For instance, a couple of respondents elaborate on how they have chosen to write two papers on the same topic, one that complies with the academic standards of three- or four-star-rated journals, and one intended for a lower-rated journal that “answers professionals' questions more and shows that things are not so simple" (\#15):

When you don't like the mainstream culture, you try to find alternative culture (...) I'm not fighting against it, but I'm looking for alternatives. Books, for example, are good alternatives. (\#11)

The respondents who develop a parallel scientific activity clearly differentiate between the projects that they conduct to meet their research objectives and the projects that they choose to conduct for more personal reasons:

There is still a little space-between two articles that bug you-to be able to write something that will interest you intellectually but that will usually be published in a lower-ranked journal and that will be of much less value than the two articles that were bugging you. (\#5) 
A few young respondents also evoke the possibility of carrying out a research activity in parallel to the one required by the system at the outset of their research. For instance, one of them explains how developing a parallel research activity has been a need since their early doctoral years:

If the idea is good and if I like something, I can do it ... for me there's no reason it shouldn't work... When I was working on my thesis, it was very hard because I really wrote four hundred pages. And to clear my head, I needed another activity in parallel... I thought to myself: I have an idea and this idea is completely crazy, but I want to dig into it a little more. So, I also wrote an article on this. (\#7)

Occasionally, a small number of respondents, mostly young but also a few middle-aged ones, share their difficulties in developing a significant parallel activity due to a lack of time or a lack of social recognition:

When I regard who among my colleagues publishes stuff for the wide public, books or polemical stuff like this, they are old profs. There is no secret. Young people like me are a bit locked in. (\#8)

Disseminating research results beyond the academic community

A few respondents, mostly middle-aged and senior ones, declare that they make the effort to communicate their research to a broader audience beyond academia-including students, professionals, and other members of civil society — even when this is not valued or required by the system. They emphasize that sharing research results with students enables them to create greater consistency between their different activities and to offer a more authentic pedagogical performance:

I seek coherence between who I am, the research I do, and the message I bring to students. I think that is important. A form of alignment... The things I observe in the field and the message I deliver to students are coherent. (\#15) 
Some of them consider the use of research projects in class to be a little risky, since students can have difficulty understanding the practical implications of using a scientific approach to think about business issues. Here is one typical example:

I do riskier courses in anthropology, philosophy, and management; there are some students who are not interested... As a result, their evaluations of the course are not as good. But I accept that. I say I accept it, because I believe in what I do. (\#1)

Sharing research data with professionals can also engender a feeling of usefulness:

Giving feedback to the company means: 'I am completely external and with my perspective, my vision, that is what I think about what is happening, that is what I perceive, that is what my recommendations are'. I think it's quite positive. (\#15)

Several respondents state that another way of having an impact beyond the academic community is to publish press articles in order "to talk about the subject with the general public" (\#25). Moreover, discussions with members of civil society make it easier for researchers to identify 'hot topics' and issues on which they can make a potential societal contribution:

A journalist contacted me two weeks ago... Our job is also to highlight certain subjects, to help with popularization. I think that's also our role. (\#19)

These moments of sharing are likely to help the researchers thrive in their research activity: "if we perform research, it's not only to publish... It's also to share something. Trying to make something known that is important to us too" (\#15).

Being involved in a research community

A few senior respondents also say that they have chosen to lead or at least to participate actively in a research community beyond just searching for publication in high-ranking journals. Thus, these respondents assert that they cannot form a research community without 
being very clear about the intellectual and scientific objectives they are targeting. This requires the ability to have a clear and relevant discourse on the scientific orientations that a group of researchers could pursue:

As you progress as a researcher, you see yourself as a producer of knowledge, but also a producer of talent. (\#12)

One respondent observes that "if you are not able to explain what you are doing simply, for me you are in a category of researcher that has no interest" (\#26). Being involved in a chosen research community is also presented as linked to the opportunity to establish friendly relationships, to cooperate, and to foster cooperation:

Do not do it alone, i.e. surround yourself, surround yourself with benevolent people, with whom you want to work in an inner circle; then in a larger circle, with people with whom you want to share things; cooperation is essential. (\#28)

Some respondents state a desire to surround themselves by people with different backgrounds and profiles in order to form dynamic and heterogeneous communities:

A value-added researcher is someone who creates a certain dynamic, creates coherence, brings together... researchers, but also civil society, public authorities, decision-making bodies, students, and parents. (\#26)

They can succeed in forming new groups of researchers by providing support to doctoral students and paying attention to the needs of young researchers:

A good researcher is one who can initiate other younger people into the field, take them by the hand, which is what I do. (\#12)

Supervising doctoral students and more generally mentoring are also cited as activities through which researchers, in particular senior researchers, can remain "committed to the system, committed to the service of the institution" (\#10). Some of them hope "to help 
doctoral students as much as possible, to help them publish, to help them to have the best possible record" (\#10):

For me, today, it gives me great satisfaction when one of my PhDs finishes and has a good career and in fact many of my PhDs have excellent careers. (\#12)

To conclude, the six ways in which respondents act virtuously as researchers are summarized in Table 2 below:

INSERT TABLE 2 ABOUT HERE

\section{Discussion}

In this paper, we have documented a third way through which academics confront the publish or perish regime, beyond mere compliance and frontal criticism. To do so, we have adopted an Aristotelian perspective on practical wisdom to analyze how thirty academics in three French business schools act 'wisely' given the constraints imposed on them, by focusing on what is within their power and in line with their best judgment.

Our results indicate that all respondents emphasize that the system pressurizes them in some ways by attempting to impose a very narrow definition of "research excellence" (Butler and Spoelstra, 2012) which consists of publishing as much as possible, if not exclusively, in topranked journals. Respondents show a very high degree of reflexivity by questioning, sometimes very strictly, the functioning and bad consequences - in particular from an ethical point of view — of the publish or perish system in which they are embedded. Indeed, no respondent appears to unproblematically accept the system or is prepared to comply unquestionably with it. As such, they all demonstrate an ability to reflect on the constraints imposed on them in the publication system as well as their opportunities for action. This 
somewhat hopeful result might be nuanced by considering that respondents evolve in a French context in which academic managerialism has been imposed quite recently, even brutally, meaning that most of them, especially middle-aged and senior academics, have spent part of their career in a different system.

Our results also reveal that most respondents consider that they still have opportunities to carry out virtuous actions, while having the impression that their room for maneuver is shrinking over time due to the growing influence of the publish or perish regime. A couple of respondents consider their behavior acratic, even if they did not use this Aristotelian terminology during the interview. Most of them do not think about themselves this way, however, at least not explicitly; instead, they focus on what is within their power and in line with their best judgment. In total, respondents describe six non-mutually exclusive ways through which they act virtuously within and beyond the publication system, namely by 'taking the time to do quality work', 'developing a personal vision', 'becoming an expert on a specific issue', 'developing a parallel scientific activity', 'disseminating results beyond the publication system', and 'being involved in a research community'. This line of results leads to several reflections.

First, it is noticeable that most respondents 'take for granted' the strengthening of the publish or perish system. Indeed, they present the current dynamic as an ineluctable 'fact' that would be beyond their power to reverse because, they believe, it is a systemic trend. Although this result might lead to the drawing of pessimistic conclusions, we believe that acting virtuously as most respondents do constitutes a very precise way to sap the power of the publish or perish system on a day-to-day basis. Following de Certeau (1984), these small steps can be regarded as 'tactics' that contribute - from both the inside and the outside of the publication system - to 'opportunistically' undermine and cause the dominant system to evolve. Indeed, respondents describe their behaviors as involving dynamics of giving, sharing, cooperating, 
and supporting their peers, which can, in turn, help the latter to do the same. These tactical behaviors can also have a broader social utility beyond academia when, for instance, researchers 'disseminate their work beyond the publication system' or develop 'a parallel scientific activity'. Of course, these behaviors will contribute to changing the system if researchers act in virtuous ways, i.e. by focusing on their power and their best judgment and by conducting activities that go "beyond sectional interests, fashionable clichés, and faddish pseudo-theories" and serve the "common good" (Alvesson et al., 2017, p. 20). By doing these virtuous actions on a daily basis, researchers can thus contribute to undermining the system and making it evolve away from the publish or perish logic.

Our results show that it is not only possible to conduct these virtuous actions beyond the publication system but also within it. This means that attempting to publish in top-ranked journals is not necessarily a sign of absolute compliance but can help in curbing the publish or perish system. Publishing "quality work" that includes "expertise" and "a personal vision" in top-ranked journals contributes in itself to fighting the publish or perish logic that promotes quantity rather than quality (Butler and Spoelstra, 2012; Clarke and Knights, 2015). Furthermore, our study shows how virtuous actions can, in certain cases, be made possible and strengthened by the system itself. For instance, some respondents described how academic requirements helped them to "develop a personal vision", "take the time to do quality work", or "become an expert in a certain field" by compelling them to increase the originality, clarity, and usefulness of their research work.

Therefore, by focusing on what is within their power and in line with their best judgment, our results indicate that researchers can find the courage - defined in the Aristotelian sense as an intermediate disposition between recklessness and cowardice (NE) - to contribute to the production of socially relevant research and to opening it up to a broader audience (Alvesson et al., 2017; Aslan, 2018). They can find the strength to reconcile, as Blondel (1893) 
indicated, what they want to do - their "willing will"- and what they do-their "willed will". All in all, this reading leads to a more optimistic view by recognizing that researchers also contribute to causing the system to evolve away from the publish or perish logic when being 'wise'.

Nevertheless, it remains true that respondents share the belief that it is beyond their power to fight against the system itself. We join the efforts of Alvesson et al. (2017) by calling on academics to consider that they have much more power to act than they often think. In de Certeau's (1984) terms, this means that academics should realize that it is within their power to act not only at a tactical level but also at a more strategic level. In this way, Alvesson et al. (2017) formulate suggestions by calling on academics to act both at an individual level and at organizational and institutional levels. For instance, they encourage academics to serve on the editorial teams of journals in order to promote alternative publications, to join assessment panels for influencing journal rankings, or to assume managerial responsibilities at school level. In addition to this participation in collective deliberations, we would like to emphasize that acting strategically also consists of deliberating on how we serve a broader socially relevant objective. We thus invite academics to consider the strategic moves that they could make in order to change the system. This requires reflecting on which broader socially relevant objectives one wants to contribute to as a researcher. Thinking about how researchers can participate in the common good could give them guidance in their daily efforts to change the publish or perish system. In the Aristotelian perspective, adopting such a common good perspective can allow individuals to conduct research activities that meet societal needs while developing skills, meaning, and virtues (Sison and Fontrodona, 2012, 2013). This perspective has the advantage of avoiding both an excessive focus on individual interests as well as a domination of community-based principles, thereby inviting researchers to combine the pursuit of community good and the pursuit of personal good (Frémeaux and Michelson, 
2017). By so doing, researchers can limit the risk of being trapped in the neo-liberal fantasy that "grips the individual, and makes individualisation, competition and instrumentality seem appealing and desirable as it offers freedom to the people" (Bal and Doci, 2018, p. 541). They can also avoid acting virtuously only in order to bear the constraints imposed on them, that is as "harmless safety valve[s]" which would be necessary to temporarily escape the system but that would not constitute a "meaningful challenge to power" (Fleming, 2005, p. 47).

The optimistic perspective discussed in the paragraph above should not prevent us, however, from pragmatically reflecting on the actual negative consequences that the publish or perish regime currently generates. At a collective level, and as already pointed out by previous contributions (Alvesson et al., 2017), many respondents argue that the current trend leads to a normalization of research activities that erodes scientific diversity and scientific progress. At an individual level, our study also confirms that academic managerialism generates a large amount of personal insecurity and other physical and psychological issues among researchers (Clarke and Knights, 2015; Vidaillet, Chemin-Bouzir and Vignon, 2018). They feel increasingly pressurized by the growing demands, excessive workloads, loss of meaning, and the promotion of individualistic behaviors. Such situations, our study reveals, can generate an awareness of acrasia, an awareness which may be a very painful emotional experience and which can be associated with alienation, and even, sometimes, with a loss of self-esteem due to perceived lack of personal courage. This might explain, at least partly, why very few respondents reflect on their behaviors in such a way, although they all participate to some extent in the publish or perish system while simultaneously criticizing it. In all cases, performing virtuous actions in such a context is also said to be at times very exhausting and difficult.

Although all researchers describe at length how pressurizing the system is, our study confirms that there are notable differences between senior and younger researchers in this respect 
(Vidaillet, Chemin-Bouzir and Vignon, 2018). Senior researchers generally appear to be less personally affected by the publish or perish pressure than younger faculty members. Similarly, they have fewer difficulties in identifying ways of acting virtuously, notably beyond the publication game, than their younger counterparts. Our study reveals that three main reasons can explain this observation. First, although tenured positions do not exist in French business schools, senior researchers' status and relative lack of career perspectives can protect them a little from the publish or perish pressure. Second, some senior researchers realize that they will be exposed to this system for a shorter time than their younger counterparts. In this respect, our study clearly shows that younger researchers are very uncertain about their future ability to cope with the pressure of the system and their ability of becoming ethical researchers in an environment where, they believe, room for maneuver is shrinking. Third, our study also suggests that experience plays a central role in helping researchers to determine what virtuous research activities are and to strengthen their willingness to dedicate themselves to them. This result thus directly echoes the Aristotelian idea that individuals develop a virtuous ethos (habit) of deliberation, judgment, and execution over time by repeating virtuous actions (Beabout, 2012; Sison et al., 2012). The role of experience in identifying the true will also illustrates Ricoeur's analysis (1992), which is part of the continuity of the Aristotelian perspective: practical wisdom is the result of a narrative unity, by which prudent people, by continuous self-correction throughout their lives, rectify their choices and, thereby, learn to act in accordance with their sense of virtue. Over time, some researchers may be able to discern between apparent desires and virtuous actions and refocus on research activities that correspond with the latter. This therefore leads to the conclusion that senior researchers have a significant responsibility to assist their younger researchers in their deliberation about what is within their power and in line with their best judgment. Our study shows that some senior researchers do indeed fully undertake their 
responsibilities by mentoring younger colleagues, leading research communities, or acting as role models. Nevertheless, their relatively privileged position also means that they have a particular responsibility, by acting more strategically to bend the rules of the publish or perish regime, by occupying managerial positions in schools, or by serving on editorial boards and assessment panels for instance.

Finally, our study opens research avenues for studying how academics deliberate about what is within their power and in line with their best judgment in contexts in which the publish or perish system is less influential—such as in public universities in France and notably in their schools of management (IAE) — or on the contrary, in the US or UK business schools, where the publish or perish regime is long-standing and more developed. Further studies could analyze the similarities and differences in both contexts on the ways researchers focus on activities that are within their power and in line with their judgment.

\section{Conclusion}

In conclusion, we would like to emphasize that this study is not only an investigation of how researchers deliberate about how they can act virtuously in the publish or perish regime but also constitutes a means for us, as researchers, to work on ourselves (Ricoeur, 1992), raising questions such as "Who am I as a researcher?"; "What is the meaning of performing research?"; and "Which research projects do I really want to work on?" Indeed, we started this research project after many informal discussions between ourselves that convinced us that the analysis of academics' experiences constitutes a virtuous means to reflect on our own experience as researchers and might help readers to reflect in turn on their experience. By doing this, we sincerely hope to contribute to the gradual undermining of the publish or perish regime by inspiring readers to focus on activities that are within their power and in line with their best judgment — in other words, to act as wise researchers. 


\begin{tabular}{|c|c|c|c|c|c|c|}
\hline Informants & Gender & Business School & $\begin{array}{c}\text { Years since } \\
\text { PhD defence }\end{array}$ & Status & Main discipline & $\begin{array}{c}\text { Duration } \\
\text { (min) }\end{array}$ \\
\hline$\# 1$ & Man & BS-1 & $15-20$ & Full Professor & Organisation Theory & 51 \\
\hline$\# 2$ & Man & BS-1 & +20 & Full Professor & Strategy / Entrepreneurship & 53 \\
\hline$\# 3$ & Woman & BS-1 & $15-20$ & Full Professor & Organisational behavior / HRM & 58 \\
\hline$\# 4$ & Man & BS-1 & +20 & Full Professor & Organisation theory & 66 \\
\hline$\# 5$ & Man & BS-1 & $5-10$ & Assistant Professor & Organisation behavior / HRM & 73 \\
\hline$\# 6$ & Man & BS-1 & $5-10$ & Associate Professor & Organisation behavior / HRM & 50 \\
\hline$\# 7$ & Woman & BS-1 & $0-5$ & Assistant Professor & Marketing & 64 \\
\hline$\# 8$ & Woman & BS-1 & $0-5$ & Associate Professor & Organisation behavior / HRM & 74 \\
\hline$\# 9$ & Man & BS-1 & $5-10$ & Associate Professor & Finance / Accounting & 58 \\
\hline$\# 10$ & Man & BS-1 & +20 & Full Professor & Strategy / Entrepreneurship & 60 \\
\hline$\# 11$ & Woman & BS-2 & $15-20$ & Full Professor & Business Ethics & 62 \\
\hline$\# 12$ & Man & BS-2 & $10-15$ & Full Professor & Finance / Accounting & 71 \\
\hline$\# 13$ & Woman & BS-2 & $10-15$ & Full Professor & Finance / Accounting & 66 \\
\hline$\# 14$ & Woman & BS-2 & $15-20$ & Full Professor & Organisation behavior / HRM & 62 \\
\hline$\# 15$ & Woman & BS-2 & +20 & Associate Professor & Corporate Social Responsability & 74 \\
\hline$\# 16$ & Man & BS-2 & $5-10$ & Associate Professor & Strategy / Entrepreneurship & 61 \\
\hline$\# 17$ & Woman & BS-2 & $5-10$ & Associate Professor & Organisation behavior / HRM & 61 \\
\hline$\# 18$ & Woman & BS-2 & $5-10$ & Associate Professor & Organisation Theory & 64 \\
\hline$\# 19$ & Woman & BS-2 & $10-20$ & Associate Professor & Marketing & 53 \\
\hline$\# 20$ & Man & BS-2 & $5-10$ & Associate Professor & Organisation behavior / HRM & 62 \\
\hline$\# 21$ & Man & BS-3 & $10-15$ & Full Professor & Strategy / Entrepreneurship & 65 \\
\hline$\# 22$ & Man & BS-3 & +20 & Full Professor & Finance / Accounting & 53 \\
\hline$\# 23$ & Man & BS-3 & $0-5$ & Associate Professor & Organisation behavior / HRM & 33 \\
\hline$\# 24$ & Woman & BS-3 & $5-10$ & Full Professor & Marketing & 52 \\
\hline$\# 25$ & Woman & BS-3 & $10-15$ & Full Professor & Organisation behavior / HRM & 32 \\
\hline$\# 26$ & Man & BS-3 & $10-15$ & Full Professor & Strategy / Entrepreneurship & 84 \\
\hline$\# 27$ & Man & BS-3 & $5-10$ & Associate Professor & Marketing & 47 \\
\hline$\# 28$ & Man & BS-3 & $5-10$ & Associate Professor & Strategy / Entrepreneurship & 61 \\
\hline$\# 29$ & Man & BS-3 & $10-15$ & Associate Professor & Organisation Theory & 61 \\
\hline$\# 30$ & Woman & BS-3 & $10-15$ & Associate Professor & Organisation Theory & 37 \\
\hline
\end{tabular}

Table 1: Sample composition 


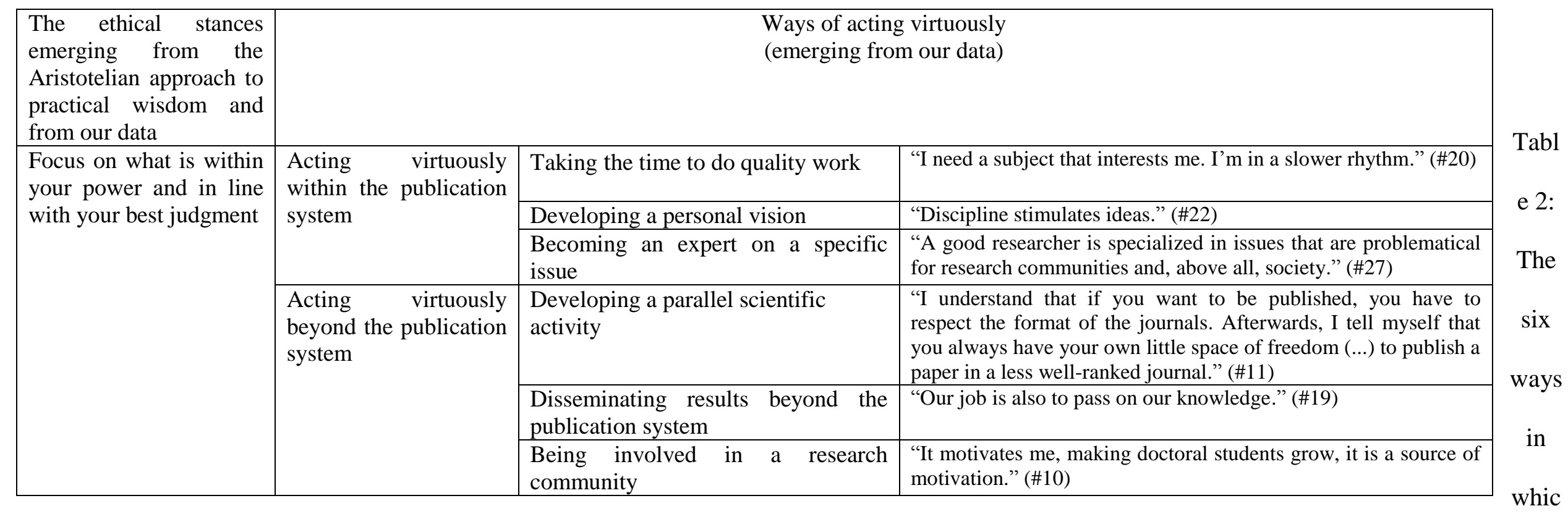

$\mathrm{h}$ respondents act virtuously as researchers 


\section{References}

Alvesson, M., Gabriel, Y., and Paulsen, R. (2017). Return to meaning: A social science with something to say. Oxford University Press.

Anderson, G. (2008). Mapping academic resistance in the managerial university. Organization 15(2), 251-270.

Archer, M., 2003. Structure, agency and the internal conversation. Cambridge University Press, Cambridge.

Archer, L. (2008). The new neoliberal subjects? Young/er academics' constructions of professional identity. Journal of Education Policy 23(3), 265-285.

Aristotle (2002). Nicomachean ethics (J. Sachs, Trans.). Focus Philosophical Library, Pullins Press, Indianapolis, IL.

Aslan, A. (2017). [Review] Mats Alvesson, Yiannis Gabriel, Roland Paulsen (2017) Return to Meaning: A social science with something to say. Management learning 49(4), 507-509.

Bachmann, C., Habish, A. and Dierksmeir, C. (2018). Practical wisdom: Management's no longer forgotten virtue. Journal of Business Ethics 153, 147-165.

Bal, P. M. and Doci, E. (2018). Neoliberal ideology in work and organizational psychology. European Journal of work and Organizational Psychology 27(5), 536-548.

Bardon, T., Brown, A. D. and Pezé, S. (2017). Identity regulation, identity work and phronesis. Human Relations 70(8), 940-965.

Beabout, J. (2012). Management as a domain-relative practice that requires and develops practical wisdom. Business Ethics Quarterly 22(2), 405-432.

Blondel, M. (1893). Action: Essay on a critique of life and a science of practice. University of Notre Dame Press.

Boje, D. M. (2001). Narrative methods for organizational and communication research. London, UK: Sage. 
Boyce, M. E. (1995). Collective centring and collective sense-making in the stories and storytelling of one organization. Organization Studies 16, 107-137.

Butler, N. and Spoelstra, S. (2012). Your excellency. Organization 19(6), 891-903.

Butler, N. and Spoelstra, S. (2014). The regime of excellence and the erosion of ethos in critical management studies. British Journal of Management 25(3), 538-550.

Butler, N., Delaney, H. and Spoelstra, S. (2018). Risky business: Reflections on critical performativity in practice. Organization 25(3), 428-445.

Callet, D, Gattet, P. and Dessimond, A. (2018). Les business schools en France. Etude Xerfi. Cammack, D. 2013. Aristotle's denial of deliberation about ends. Polis 30(2), 228-250.

Clarke, C. A., Knights, D. and Jarvis, C. (2012). A labour of love? Academics in business schools. Scandinavian Journal of Management 28(3), 5-15.

Clarke, C. A. and Knights, D. (2015). Careering through academia: Securing identities or engaging ethical subjectivities? Human Relations 68(12), 1865-1888.

Davies, B. and Peterson, E. B., (2005). Intellectual workers (un)doing neoliberal discourse. Critical Psychology 13, 32-54.

de Certeau, M., (1984). The practice of everyday life. University of California Press, Berkeley.

Dubois, S. and Walsh, I. (2017). The globalization of research highlighted through the research networks of management education institutions: The case of French business schools.M@n@gement 20(5),435-462.

Dunne, S., Harney, S. and Parker, M. (2008). Speaking out: The responsibilities of management intellectuals: A survey. Organization 15(2), 271-282.

Edwards, M. A. and Roy, S. (2017). Academic research in the $21^{\text {st }}$ century: Maintaining scientific integrity in a climate of perverse incentives and hypercompetition. Environmental Engineering Science 34(1), 51-58. 
Fleming, P. (2005). Metaphors of Resistance. Management Communication Quarterly 19(1), 45-66.

Frémeaux, S. and Michelson, G. (2017). The common good of the firm and humanistic management: conscious capitalism and economy of communion. Journal of Business Ethics 145(4), 701-709.

Frémeaux, S., Michelson, G. and Noël-Lemaitre, C. (2018). Learning from Greek philosophers: The foundations and structural conditions of ethical training in business schools. Journal of Business Ethics 153(1), 231-243.

Gadamer, H.-G. (2004/1975). Truth and method, 2nd edition. Continuum, London.

Hartman, E. M. (2013). Virtue in business. Conversations with Aristotle. Cambridge University Press, Cambridge.

Holt, R. (2006). Principals and practice: Rhetoric and the moral character of managers. Human Relations 59(12), 1659-1680.

Jeanes, E. (2017). Are we ethical? Approaches to ethics in management and organization research. Organization 24(2), 174-197.

Kolnai, A. (2001). Deliberation is of ends, in Millgram, E. (ed.), Varieties of Practical Reasoning, The MIT Press, Cambridge - London.

Küpers, W. M. and Pauleen, D. J. (2013). A handbook of practical wisdom. Leadership organization and integral business practice. Gower Publishing, Surrey.

Locke, R. R. and Spender, J. C. (2011). Confronting managerialism: How the business elite and their schools threw our lives out of balance. Zed Books, London.

Mitroff, I. I. (2004). An open letter to the deans and faculties of American business schools. Journal of Business Ethics 54(2), 185-189.

Moriceau, J. L., Laroche, H. and Jardat, R. (2017). Recherche en gestion, le sens mis en pièces. Revue Francaise de Gestion 6(267), 67-78. 
Murillo, D. and Vallentin, S. (2016). The business school's right to operate: Responsibilization and resistance. Journal of Business Ethics 136(4), 743-757.

Nonaka, I., Toyama, R. and Hirata, T. (2008). Managing flow: A process theory of the knowledge-based firm. Volume 19. Palgrave Macmillan, New York, NY.

Nonaka, I., Chia, R., Holt, R. and Peltokorpi, V. (2014). Wisdom, management and organization. Management Learning 45(4), 365-376.

Pearce, J. L. and Huang, L. (2012). The decreasing value of our research to management education. Academy of Management Learning and Education 11(2), 247-262.

Rhodes, C. \& Brown, A. D. (2005). Narrative, organizations and research. International Journal of Management Reviews 7(3), 167-188.

Ricoeur, P. (1992). Oneself as another. University of Chicago Press, Chicago, IL.

Roberts, J. (2005). The power of the imaginary in disciplinary processes. Organization 12(5), 619-642.

Robinson, S., Ratle, O. and Bristow, A. (2017). Labour pains: Starting a career within the neoliberal university. Ephemera: Theory \& Politics in Organization 17(3), 481-508.

Shotter, J. and Tsoukas, H. (2014). In search of phronesis: Leadership and the art of judgment. Academy of Management Learning and Education 13(2), 224-243.

Sigurjonsson, T., Vaiman, V. and Arnardottir, A. (2014). The role of business schools in ethics education in Iceland: The managers' perspective. Journal of Business Ethics 122(1), $25-38$.

Sigurjonsson, T., Arnardottir, A., Vaiman, V. and Rikhardsson, P. (2015). Managers' views on ethics education in business schools: An empirical study. Journal of Business Ethics 130(1), 1-13.

Sison, A. J., Hartman, E. M. and Fontrodona, J. (2012). Reviving tradition: Virtue and the common good in business and management. Business Ethics Quarterly 22(2), 207-210. 
Sison, A. J. and Ferrero, I. (2015). How different is neo-Aristotelian virtue from positive organizational virtuousness? Business Ethics: A European Review 24(S2), S78-S98.

Sison, A.J. and Fontrodona, J. (2012). The common good of the firm in the AristotelianThomistic tradition. Business Ethics Quarterly 22(2), 211-246.

Sison, A.J. and Fontrodona, J. (2013). Participating in the common good of the firm. Journal of Business Ethics 113(4), 611-625.

Tourish, D. and Willmott, H. (2015). In defiance of folly: Journal rankings, mindless measures and the ABS Guide. Critical Perspectives on Accounting 26(1), 37-46.

Tourish, D. (2017). [Review] Mats Alvesson, Yiannis Gabriel, Roland Paulsen (2017) Return to Meaning: A social science with something to say. Organization Studies 39(4), 585-591.

Vidaillet, B., Chemin-Bouzir, C. and Vignon, C. (2018). Les nouveaux risques du métier : protéger les jeunes enseignants-chercheurs en gestion. Le Libellio 14(4), 67-71.

Weick, K. E. (1995). Sensemaking in organizations. Thousand Oaks, CA: Sage Publications.

Weick, K. E., Sutcliffe, K. M. and Obstfeld, D. (2005). Organizing and the process of sensemaking. Organization Science 16, 409-421.

Weil, S. (1952). Gravity and grace. New York: G.P. Putnam's Sons.

Willmott, H. (1995). Managing the academics: Commodification and control of university education in the UK. Human Relations 48(9), 993-1028.

Willmott, H. (2011). Journal list fetishism and the perversion of scholarship: Reactivity and the ABS list. Organization 18(4), 429-442. 